\title{
The Determinants of Small Firm Growth in the Greek Manufacturing Sector
}

\author{
F. Voulgaris \\ Technological Educational Institute of Crete \\ D. Asteriou \\ City University London \\ G. Agiomirgianakis \\ Hellenic Open University, Greece, and City University London
}

\begin{abstract}
The aim of this paper is twofold; first, to identify the variables that mostly affect rapid sales growth in Greek manufacturing small and medium sized enterprises (SMEs); second, to examine the potential influence upon business growth and performance outcomes of those variables representing enterprise and financial management characteristics of the Greek SMEs. The study utilizes panel data of a random sample of 143 firms from the manufacturing SMEs sector in Greece. Regression analysis is used to determine the explanatory factors of rapid sales growth. This paper is firstly addressing the Greek case and our results are in line with the findings of other empirical studies in the European Union (EU), thus, supporting the convergence hypothesis among member states in EU. Indeed, factors found to influence significantly manufacturing SMEs growth in Greece are profitability, liquidity, reliance on long-term debt, employee productivity, fixed

*Corresponding address: Professor George Agiomirgianakis, Hellenic Open University, Riga Fereou 169 \& Tsamadou Sts. GR-26222, Patra Greece Tel: 30-2610-362554, Fax 30-2610-361410, E-mail: gmagios @eap.gr

Professor F. Voulgaris, Technological Educational Institute of Crete, Agios Nikolaos Branch GR-72100 Agios Nikolaos, Crete, Greece Tel: 30-28410-28834 Fax: 30-28410-82884, E-mail: bellevue@ otenet.gr Dr. Dimitrios Asteriou, City University, Department of Economics, Northampton Square, EC 1V OHB London, UK Tel: 44-207-040-8591 Fax: 44-207-040-8580, E-mail: D.Asteriou@city.ac.uk (c)2003-Center for International Economics, Sejong Institution, All Rights Reserved.
\end{abstract}


assets turnover and restricted sales credit terms. Moreover, our findings also suggest that SMEs located in big cities behave differently from firms located in the periphery with regard to factors related to growth. The same holds true for firms in different industry subgroups. Our findings give rise to several policy implications that are crucial for the competitiveness of the sector, especially in view of the changes induced by the European Monetary Union, as well as, by other undergoing economic changes in the country such as the Olympic Games 2004. Policies such as low cost financing, lower tax burdens, incentives for investments in new technology, continuous personnel training, promotion of ecommerce and cooperation with foreign firms might induce fast growth in Greek SMEs.

- JEL Classifications: G32, L6, L11, C23

- Key words: Capital structure, Industry study, Manufacturing, Panel data

\section{Introduction}

It is generally recognized that small and medium sized enterprises (SMEs) play an important role in the European Union (EU), in terms of economic growth and development with a particular contribution in terms of employment generation. This is particularly true in the case of Greece ${ }^{1}$ that is literally a country of SMEs since they comprise $99.8 \%$ of total firms, contributing $91 \%$ to total employment and $30 \%$ to manufacturing value added. Moreover, Greek SMEs demonstrate a strong contribution to economic growth, both regionally and nationally ${ }^{2,3}$.

In the last decades, globalization has resulted in an increasing competition in most product and service markets worldwide. This is especially true for the EU countries following the European Integration process. However, while increasing competition affects firms of all sizes, there are size-related characteristics that can affect the ability of SMEs to respond to such changes. In view of the foregoing changes, the survival of SMEs is crucial to the Greek economy, particularly in the

\footnotetext{
${ }^{1}$ SMEs in Greece are defined as those firms that employ up to 100 persons.

${ }^{2}$ It should be noted at this point, that exceptionally important to economic growth are the fast growing SMEs, which are viewed as only the top $5-10 \%$ of all growing firms according to the OECD SMEs outlook (2000).

${ }^{3}$ For a literature review on the Greek SMEs, see among others EOMMEX (2000), KEPE (1989) and Voulgaris et al. (2000)
} 
manufacturing sector. In addition to the above, it is generally accepted that rapidly expanding firms account for a large part of job creation. The question, therefore, is how Greek SMEs will meet successfully the challenges imposed by the deepening of the European Integration process and at the same time to be able to achieve rapid expansion.

A well-accepted measure of dynamism and competitiveness in a firm is rapid sales growth. A study on the factors that may affect fast sales growth could give an insight to managers and policy makers alike on what is required by an SME in order to sustain or achieve dynamism.

The purpose of this paper is to identify the variables correlated with rapid sales growth in the Greek manufacturing SMEs, based on the hypothesis that fast growing SMEs are firms with the least negative effect from European Integration. According to the European Observatory for SMEs (1997), 46\% of European SMEs of the size class of 50-249 employees regarded European Single Market as an opportunity for growth and $18 \%$ as a threat. However, the small firms (especially the micro firms) saw no opportunities from the larger selling market, because of the increased competition. On the contrary, Eurostat data show that European Integration has been beneficial to European exports and particularly to exports of very small enterprises.

The period of our study (1988-1996) is characterized by drastic macroeconomic changes and policy measures undertaken in Greece in order to satisfy the convergence criteria set out by the Maastrich Treaty. ${ }^{4}$ Furthermore, trade barriers were alleviated at that time in accordance with the rules imposed by the European Union. Also, the liberalization of the banking sector in 1992, combined with the integration of national capital markets among member states, has affected positively the growth of Greek firms by supporting adequate funding.

The focus of our paper is on the impact of financial management characteristics upon business growth amongst manufacturing SMEs in Greece. Due to lack of qualitative data, such as degree of innovation, educational level of employees, management practices, collaboration with other SMEs etc., the study was restricted to financial ratio characteristics. Panel data of a sample of 143 manufacturing SMEs are used covering a period of nine years (1988-1996) and includes firms from 15 different branches of industry. Review of the literature

\footnotetext{
${ }^{4}$ Among these convergence criteria were the inflation rates, interest rates, government deficits and public debt ratios
} 
shows that the aspect of determinants of growth in the Greek manufacturing industry has not been investigated up to the present time.

The paper is organized as follows. In Section 2, we review the available empirical evidence on the factors that may affect business growth and on the significance of financial management characteristics amongst growing SMEs. In Section 3, we analyze the research method, the variables used and the econometric techniques applied. In Section 4, contains concluding remarks and the policy implications of our findings for the competitiveness of the sector, in view of the undergoing economic changes following European unification.

\section{Literature Review}

All business success, as well as small business success, is predominantly measured in either increases in turnover or revenue or increases in the number of employees (Berkham et al., 1996, Holmes and Zimmer, 1994, Acs and Audretsch, 1990). Many empirical studies have tested the factors that may influence a firm's expansion. According to Brockhaus and Horwitz (1985), for example, the most important factor of successful growth is the attitude of the owner-manager. Many entrepreneurs choose not to grow because of fear of loss of personal control of the firm, fear of having to go into debt or reluctance to pass the responsibility of running the business over to professional managers. Jones (1992) suggests that impediments to growth could also be due to: (i) a low access to financing and to sources of information and technology; (ii) lack of technical and managerial skill and inadequate organizational adaptability and (iii) the ability to acquire or use new technology.

The lack of resources experienced by most SMEs suggests that substantial benefits might be obtained through the development of strategic partnerships with other SMEs or even large-size firms. Malecki and Tootle (1996) suggested the need for developing networks capable of delivering economies of scale and greater market penetration. Almus and Nerlinger (1999) also found that partnerships with other firms correlated with greater growth rates. Especially for manufacturing SMEs the importance of developing mutually beneficial relationships with buyers is a critical success factor. Acquisitions and mergers may affect growth rates by changing resource availability that promotes or inhibits growth.

Financial management characteristics found to correlate with firm growth were: 
low liquidity and high gearing. Hutchinson and Ray (1986), in a study on rapidly growing small firms in UK, showed that growth results in low liquidity and high gearing. The low liquidity in those firms is related to the large investment fund need associated with limited accessibility to capital markets. Therefore, there is a critical need for those firms for improved financial control and efficient use of their limited resources. Mira (2002), in a study on the capital structure of Spanish SMEs, found also that growth correlates with more debt in the capital structure of those firms.

In addition to high financial gearing, high total and fixed assets turnover are factors associated with growth, according to Gupta' study (1969). However, Gupta argues that very small companies may register very high growth rates due to the fact that growth is calculated at a lower base. According to Guptaís study, profitability is not related to growth of sales, since some companies may be able to maintain high profits, even with a declining growth rate, because of an oligopolistic market structure or barriers to entry. Moreover, Acs and Audretsch (1990) tested through a regression analysis certain variables on growth in U.S. manufacturing SMEs. The results show that small firm growth is negatively related to the industry capital intensity, advertising intensity and the extent of unionization. On the other hand, it is positively correlated to the extent of human capital and the amount of innovation in an industry ${ }^{5}$.

In addition to the financial management characteristics, based on a number of European empirical studies, see e.g. European Observatory 1996, other factors found to influence a rapid growth in European SMEs are: strong marketing orientation, emphasis on quality and innovation, flexibility in production, strong orientation towards the implementation of strategic thinking and planning mechanisms, reinvestment of profits in the enterprise, organizational complexity, high educational qualifications, decentralized and participative style, continuous training of entrepreneurs/managers and use of more external information and advice services.

European Networks for SMEs Research states that the Internal Market program has had a positive impact on the growth of real turnover of European enterprises. However, empirical research showed that the statistically significant determinants of turnover growth with positive influence were strategic market position,

${ }^{5}$ O'Farrell and Hitchens (1988), Gibb and Davies (1990) and Hall (1994) provide substantial reviews of prior research attempted to explain the dynamics of growth in SMEs. 
proactive strategies with regard to quality and new technology, subcontracting (being the main supplier) and continuing management training. Increased cross border competition and tax burden exert a negative impact on European SMEs growth.

So far, studies on the Greek industry have not examined variables associated with growth in SMEs. They mainly deal with factors affecting entry and exit of firms without discriminating for size (Chassid and Katsos, 1992; Droukopoulos and Thomadakis, 1993; Anagnostaki and Louri, 1994, 1995) and the impact that location within an agglomeration has on the likelihood of survival for Greek firms. Droukopoulos and Thomadakis (1993), using data from 1983 sought to explain intersectoral differences of SME sales shares in Greek manufacturing. SMEs were divided into four size strata, establishments employing 10-19, 20-20, 30-49 and 50-99 persons. Cross-sectional regression for each stratum was used to discover significant determinants of shares. They found that capital intensity and relative efficiency in the sector had significant effect on sales shares of SMEs. The same authors, in a later study, which was actually an extension of their previous work, examined the change in sales shares of various size classes of SMEs over the period 1983-90.

In a study on the impact of Single Market on Greek firms, undertaken by the National Statistical Service of Greece, (1997), it was shown that the positive impact was associated with the size, the involvement of the firm in other enterprises and the sector of economic activity the firm belonged.

\section{Methodology and Empirical Results}

The aim of the study is to estimate empirically the factors determining the variation in average small-firm growth. For this purpose, pooled regressions are estimated with dependent variable (proxying small-firm growth) the annual sales growth for each firm and for the specific time period. According to theoretical views and empirical research findings explained above, a large set of variables was used as regressors. Emphasis is placed though on financial management characteristics and productivity ratios, due to lack of other qualitative variables, which would require questionnaires to be sent to each firm, a task that could be carried out in a future study.

Based on the theory and empirical findings, we hypothesized that positive effects on the growth of SMEs are expected from the following explanatory 
variables:

a) Profitability, measured either as net profit margin (i.e. net profit over sales), return on investment (i.e. net profit over total assets), or return on equity.

b) Debt leverage and structure, which can be quantified as total liabilities to total assets and as long-term debt to total debt.

c) Degree of productivity proxied by sales to number of employees.

d) Asset structure measured as net fixed assets to total assets.

e) Capital turnover expressed as sales to net fixed assets and sales to total assets.

f) Exports, measured as the percentage of exports over total sales.

On the other hand, variables expected to affect negatively Greek SMEs fast sales growth employed in our analysis include:

a) Liquidity, measured by the rate of current assets to current liabilities.

b) Credit policy, proxied by average creditor days offered to customers.

c) Suppliersí credit, indicated by the average creditor days offered by suppliers.

d) Average stock levels, measured as inventory to sales times 360, considered as an indication of better stock management or more buoyant demand for their products.

Finally, two more explanatory variables were included capturing the size and the age of each SME. Size in our analysis is proxied by the ratio of total assets over the number of employees. Based on theory and literature, total assets or number of employees could also be alternatively considered, but the specific variable used in the analysis is considered as inclusive of the other two. For the age, two alternative proxies were used, first, a variable showing the years that each firm is under operation and second, a dummy variable that takes the value of 1 for firms with less than 5 years in operation, 2 for firms with more than 5 but less than 10 years in operation, and 3 for firms with more than 10 years in operation, (measured by the age of firm in 1988). The data set is constituted by the Balance Sheet and Income Statement accounts of a random sample of 143 manufacturing SMEs in Greece plus 14 financial ratios $^{6}$, shown in Table 1, extracted from the database of ICAP Hellas, a Greek financial and business information service company.

The data set covers the period 1988-1996 (Panel Data with $\mathrm{N}=143, \mathrm{~T}=9$ ) and includes firms from 15 different industries based in both the major and industrially

\footnotetext{
${ }^{6}$ The construction of the financial ratios has been calculated by the authors. Data are available upon request.

${ }^{7}$ Namely, Athens (including the greater Athens area and Piraeus) and Thessalonica.
} 
Table 1. Financial ratios

\begin{tabular}{lcc}
\hline \multicolumn{1}{c}{ Class } & Code & Ratio \\
\hline $\begin{array}{l}\text { 1. Solvency } \\
\text { (a) Short-Term Liquidity }\end{array}$ & X1 & Current Assets to Current Liabilities \\
2. Managerial Performance & & \\
(a) Asset-Equity Structure & X2 & Net Fixed Assets to Total Assets \\
(b) Financial Leverage & X3 & Long-term Debt to Total Debt \\
& X4 & Total Liabilities to Total Assets \\
(c) Inventory & X5 & Inventory x 360 to Sales \\
(d) Credit Policy & X6 & Creditors X 360 to Sales \\
(e) Suppliers Credit & X7 & Accounts Payable X 360 to Sales \\
(f) Administration & X8 & Sales to No of Employees \\
3. Profitability & & \\
(a) Capital Turnover & X9 & Sales to Net Fixed Assets \\
& X10 & Sales to Total Assets \\
(b) Profit Margin & X11 & Net Profit to Gross Profit \\
(c) Return on Investment & X12 & Net Profit to Net Worth \\
& X13 & Net Profit to Total Assets \\
4. Size & & \\
\end{tabular}

developed Greek cities ${ }^{7}$, as well as, the Greek peripheral cities (see Table 2). The allocation of sample firms in the industrial sectors follows the one in the real population. The character of data set allows us to use a panel data methodology which has considerable advantages over the cross-sectional alternative (see Baltagi, 1995).

The model can be described by the following equation:

$$
y_{i t}=\mu_{i}+\sum_{j=1}^{n} \beta_{j} x_{j, i t}+u_{i t}
$$

where $y_{i t}$ is the depended variable, regressed on a unobservable individual effect, $\mu_{i}$, that does not depend on time ${ }^{8}$ and a $j$ set of regressors $x_{j, i t}$. Obviously, is the random error component and in all cases $i$ denotes firms and $t$ denotes time. Arellano and Bover (1990) suggest that the use of panel data in this kind of research is the most appropriate one because it allows for firm heterogeneity and it also reduces collinearity among the variables that are used. One critical question

${ }^{8}$ This, for example, can capture the entrepreneurial or managerial skills of each firmís executives. 
Table 2. Allocation of sample firms by industry sector, large cities and periphery subgroups

\begin{tabular}{lclc}
\hline \multicolumn{1}{c}{ Sectors } & No. of Firms & Sectors & No. of Firms \\
\hline All firms & 143 & Machinery & 19 \\
Firms based in large cities & 104 & Metals & 11 \\
Firms based in periphery & 39 & Non metals & 12 \\
Chemicals & 13 & Paper & 5 \\
Drinks & 4 & Plastic & 11 \\
Food & 10 & Printing & 10 \\
Furniture & 4 & Sundry & 8 \\
Garments & 16 & Textiles & 13 \\
Leather & 4 & Wood & 3 \\
\hline
\end{tabular}

in panel data models is whether the unobservable individual effects are fixed or random. To verify the character of the individual effects, the Hausmanís (1978) specification test is utilized. In our case the Hausman test indicated as appropriate model the fixed effects model, which requires to transform our original model, subtracting the average of the variables from it.

Table 3 presents results for the whole sample of 143 firms, each time adding one more explanatory variable to the equation that tries to identify the primary determinants of small-firms fast growth. Each variable was regressed as explanatory variable one by one to see its effect on firmís growth. Alternative models were applied adding each time an additional indicator to see the interrelationship among variables and how the first results were affected. This procedure is somehow similar to the stepwise regression, detecting significant determinants of the dependent variable, and simultaneously avoiding all the drawbacks of the stepwise regression approach (see Derksen and Keselman, 1992). Significance was defined at a probability of 0.05 or less.

We present our findings in Table 3 below. Initially, the effect of age and size are examined. Age is used according to both definitions explained above and in both cases it appeared to be insignificant, suggesting that there is no effect of maturity on small-firm growth. This is in contrast to the findings of other studies, which indicate age as an important factor in determining business growth (see e.g. Storey, 1994, Wagner, 1995, Wijewardena and Tibbits, 1999). On the other hand, the size variable appears to be statistically significant at the $10 \%$ level, when entered by itself, but its significance becomes smaller when adding other

${ }^{9}$ Similarly, see Evans (1987) and Hall (1987) for the U.S. 
determinants, as explanatory variables. It is interesting to note at this point that in our model size appears to affect negatively sales growth. This finding agrees with other studies abroad, e.g., Almus and Nerlinger (1999) for high-tech firms in Germany and Wagner (1995) for manufacturing firms in Lower Saxony ${ }^{9}$. It is not surprising to find that small companies register high growth rates because growth is calculated on a lower base and because they need to rapidly achieve the minimum efficient size.

The variable exports in all cases was insignificant, while it is notable to say that the insignificance of exports and age was not at all affected by the inclusion or exclusion of other variables in our regression model. This can be explained by the fact that exporting firms are exposed to alien conditions versus SMEs that limit themselves to the domestic market (Haati et al., 1998). Exports have been found to associate with fast growth in firms with wholly owned foreign subsidiaries, something that does not hold for the majority of Greek SMEs.

Size is measured as total assets over the number of employees.

Age is proxied by a dummy that takes the value of 1 for firms with less than 5 years in operation, 2 for firms with more than five but less than 10 years of operation and 3 for firms with more than 10 years of operation (measured by the age of firm in 1988).

Exports is proxied by percentage of exports over sales.

Liquidity is measured as current assets to current liabilities (X1).

Profitability 1 is measured by the ratio of net profit to sales, while Profitability $\mathbf{2}$ is measured by the ratio of net profit to total assets (X13).

Managerial Performance 1, 2 and 3 are proxied by the ratios of net fixed assets over total assets (X2), long-term debt over total debt (X3) and total liabilities over total assets (X4). Administration is proxied by sales over number of employees (X8).

Credit Policy is measured by creditors over sales (X6); alternative measures did not alter the results $\tilde{n}$ see text for more details.

Capital Turnover is measured by sales to net fixed assets (X9); alternative measures did not alter the results $\tilde{n}$ see text for more details.

Table 3 presents our findings for eight specifications of the regression equation. Regressions 1 and 2 report the summary results including, alternative measures for the profitability of SMEs. Both measures (namely the profit margin and the return 
Table 3. Panel data analysis - Summary results for all firms dependent variable: Growth of sales; Method: Pooled least squares; Sample: 19881996

\begin{tabular}{|c|c|c|c|c|c|c|c|c|}
\hline Variable & Reg 1 & $\operatorname{Reg} 2$ & $\operatorname{Reg} 3$ & $\operatorname{Reg} 4$ & $\operatorname{Reg} 5$ & Reg 6 & $\operatorname{Reg} 7$ & $\operatorname{Reg} 8$ \\
\hline \multirow[t]{2}{*}{ Constant } & 0.401 & 0.377 & 0.408 & 0.384 & 0.364 & 0.292 & 0.466 & 0.480 \\
\hline & $(2.84)^{*}$ & $(2.67)^{*}$ & $(2.89) *$ & $(2.71)^{*}$ & $(2.56)^{*}$ & $(1.87)^{* *}$ & $(2.62)^{*}$ & $(2.73)^{*}$ \\
\hline \multirow[t]{2}{*}{ Size } & -0.029 & -0.028 & -0.027 & -0.028 & -0.023 & -0.024 & -0.032 & -0.029 \\
\hline & $(-1.94)^{* *}$ & $(-1.82)^{* *}$ & $(-1.79)^{* * *}$ & $(-1.86)^{* *}$ & $(-1.53)$ & $(-1.60)$ & $(-1.34)$ & $(-1.34)$ \\
\hline \multirow[t]{2}{*}{ Age } & 0.014 & 0.014 & 0.014 & 0.011 & 0.014 & 0.017 & 0.013 & 0.008 \\
\hline & $(1.06)$ & (1.07) & (1.09) & $(0.87)$ & (1.12) & (1.28) & $(0.65)$ & $(0.65)$ \\
\hline \multirow[t]{2}{*}{ Exports } & 0.0002 & 0.0001 & 0.0002 & 0.0001 & 0.0002 & 0.0002 & 0.0002 & 0.0001 \\
\hline & $(0.49)$ & $(0.39)$ & $(0.39)$ & $(0.46)$ & $(0.68)$ & $(0.63)$ & $(0.68)$ & $(0.45)$ \\
\hline Profitability 1 & $\begin{array}{c}0.316 \\
(2.57)^{*}\end{array}$ & - & - & - & - & - & - & - \\
\hline \multirow[t]{2}{*}{ Profitability 2} & - & 0.342 & 0.376 & 0.398 & 0.417 & 0.421 & 0.355 & 0.321 \\
\hline & & $(2.95)^{*}$ & $(3.22)^{*}$ & $(3.40)^{*}$ & $(3.54)^{*}$ & $(3.53)^{*}$ & $(2.99)^{*}$ & $(2.69)^{*}$ \\
\hline \multirow[t]{2}{*}{ Liquidity } & - & - & -0.022 & -0.022 & -0.034 & -0.011 & -0.027 & -0.040 \\
\hline & & & $(-2.27)^{*}$ & $(-2.27)^{*}$ & $(-3.14)^{*}$ & $(-1.04)$ & $(-2.50)^{*}$ & $(-3.52)^{*}$ \\
\hline $\begin{array}{l}\text { Managerial } \\
\text { Perform } 1\end{array}$ & - & - & - & $\begin{array}{c}0.109 \\
(191)^{* *}\end{array}$ & - & - & - & - \\
\hline Managerial & - & - & - & - & 0.143 & - & 0.149 & 0.140 \\
\hline Perform. 2 & & & & & $(2.41)^{*}$ & & $(2.52)^{*}$ & $(2.36)^{*}$ \\
\hline $\begin{array}{l}\text { Managerial } \\
\text { Perform. } 3\end{array}$ & - & - & - & - & - & $\begin{array}{c}0.113 \\
(1.75)^{* *}\end{array}$ & - & - \\
\hline Admini- & - & - & - & - & - & - & 0.026 & 0.024 \\
\hline Stration & & & & & & & $(2.54)^{*}$ & (1.15) \\
\hline Credit policy & - & - & - & - & - & - & $\begin{array}{l}-0.0004 \\
(-2.58)^{*}\end{array}$ & - \\
\hline $\begin{array}{l}\text { Capital } \\
\text { Turnover }\end{array}$ & - & - & - & - & - & - & - & $\begin{array}{l}-0.0003 \\
(-2.72)^{*}\end{array}$ \\
\hline $\mathrm{R}^{2}$ & 0.213 & 0.215 & 0.221 & 0.228 & 0.228 & 0.224 & 0.243 & 0.244 \\
\hline Adjusted $\mathrm{R}^{2}$ & 0.208 & 0.210 & 0.215 & 0.221 & 0.221 & 0.218 & 0.234 & 0.235 \\
\hline F-statistics & $2.82 *$ & $3.34 *$ & $3.72 *$ & $4.10^{*}$ & $4.10^{*}$ & $3.62 *$ & $4.86^{*}$ & $4.95^{*}$ \\
\hline
\end{tabular}

$*, * *$ indicate statistical significance at the $95 \%$ and $90 \%$ level of confidence, one-tailed test.

on investment) are statistically significant and enter the equation with the expected positive sign. This does not agree with other empirical studies (Roper, 1999), since profitability does not necessarily have to be positively correlated to growth, especially when the concept of sales growth is used, as in the present study. When companies expand not in response to extra-profit opportunities but in response to trade position motivation, sales increase may or may not be positively associated with growth. Furthermore, some companies may maintain high profits because of 
a dominant position in their industry or high barriers to entry and an oligopolistic market structure (see Literature Review). Apparently, the above do not hold for Greek manufacturing SMEs, because they operate in a competitive environment and, due to the difficulty in obtaining external financing, they had to rely on their ability to generate profits in order to grow. This was especially true for the period under study, because of the prevailing high interest rates and the tight monetary policy.

Regression 3 includes the liquidity measure, while we keep from profitability the second of its proxies (i.e. Net Profit over Total Assets), as it was more significant than the first. Again, the results are significant for the $95 \%$ level and the sign is according to the theoretical suggestions. Current ratio is found to be negatively associated with growth. The lower liquidity of the fast growing firms is related to their basic fund demand-supply equation, which forces them to economize on use of funds in current asset holdings and to borrow from all possible sources, including banks and trade creditors. Gupta (1969) and Ray and Hutchinson (1983) provide evidence that business enterprise growth results, particularly in financial stresses, such as incipient overtrading, low liquidity and high gearing. They go on to argue that if the many financial pitfalls of growth are to be avoided, there is a critical need for improved financial management.

Regressions 4, 5 and 6 introduce different measures that capture asset structure and debt leverage. From the three alternative measures the reliance on Long-term Debt appears to be the most important (being significant for the $95 \%$ level), while the other measures are significant for the $90 \%$ level. Here, it is important to note that after the addition of the leverage and asset structure variables, the size variable drops in terms of significance, suggesting that these measures are more important determinants of small firmsí growth. All three measures affect growth positively. This is in accordance with the literature, (Gupta, 1969, Ray and Hutchinson, 1983, McMahon, 2000), and can be attributed to SMEs' greater desire for financial structure flexibility plus the fact that debt magnifies the return to equity and provides the necessary funds for new investments and growth. For Greek SMEs, this is also an indication of lack of adequate cash flow funds to support fast growth. Fast growing firms must increase capacity and, therefore, they undertake new investments in fixed assets. This results in higher Net Fixed Assets to Total Assets ratio and higher use of long-term debt financing those assets.

Finally regressions 7 and 8 include additional variables for the effect of employee productivity, credit policy and capital turnover. Employee 
productivity is significant and positive, as expected, while the other two variables are negative and significant as well. The association of low capital turnover with growth suggests that fast-growing firms are capital intensive with high value added and that fast growth requires application of new technology through new investments in fixed assets. Securing prompt payment from customers is an indication of greater need of funds, but of general efficiency as well, which is then reflected in higher rates of growth giving a negative correlation between growth and customer credit terms. Alternative models including different proxies for credit policy and capital turnover were estimated, but they did not affect the result significantly. Other variables used in the model, such as suppliers' credit and inventories build-up did not appear significant in our model. Their absence provides insight into their influence on growth rates of Greek manufacturing SMEs ${ }^{10}$.

In order to test the robustness of those findings, all the above regression models were estimated, splitting the sample into 104 firms based on large cities and 39 firms based on the Greek periphery. The results did not seem to alter significantly for both of these sub-samples, confirming our prior findings about the appropriateness of the alternative variables in usage, however, as we shall see shortly this approach also allows us to get useful insights into the differences between large cities and periphery firms. The $\mathrm{R}^{2}$ statistics although a little low, is increasing with each additional variable and the F-statistics shows in all cases that the model is appropriate. Furthermore, considering other similar studies (Roper 1999, Davidsson et al., 2000 and McMahon, 2000), $R^{2}$ values between 0.20 and 0.40 are considered very satisfactory. In this case, $R^{2}$ values are small because other very important qualitative factors have not been taken into account, such as human capital of employees (i.e. level of training, qualifications, age etc.) as well as management educational level and training, ownership (foreign, subsidiary or not), attitude of owner-manager, partnerships, quality of products, innovation, use of new technology, strategic awareness etc., as mentioned previously in this study.

Having established the most important measures regarding each category of explanatory variables, we proceed by establishing the parsimonious model from the above analysis for different sub-samples and industrial sectors in order to have a comparative analysis. Summary results of those regressions are presented in

\footnotetext{
${ }^{10}$ Total assets was also used as a size variable in the model and we found out that the results were not affected due to the fact that the number of employees did not change significantly through the years for most of the firms
} 
Table 4.

It is interesting that in the big city subgroup, in addition to the other factors found to affect significantly growth for all SMEs, exports play also a significant role, as opposed to the periphery subgroup of firms. This suggests that immediate access to transport means and the use of external support (either in the form of information or advice), are more easily available to firms based in the big cities. It can also be assumed that these firms are characterized by a higher level of organization and management and possibly increased cross border business contacts. Periphery firms however, (consisting mainly of food, machinery and textiles), are mainly oriented towards the domestic market and as of that show a negative correlation between sales growth and exports, which is significant only for the food industry subgroup as expected. Big-city fast growing Greek SMEs do not seem to be affected by liquidity problems vs. periphery. As shown in Table 4, profitability and long-term debt leverage do not affect sales growth in periphery SMEs, but periphery firms seem to economize on short-term funds (liquidity and credit policy variables). The profitability factor is found non-significant for Greek periphery firms in line with other findings abroad. The non-reliance on long-term debt can be explained by the fact that manufacturing firms established outside of big cities are favored by grant subsidies on new investments.

The regression models of the industrial sector subgroups also give an interesting view of factors affecting growth. The industrial sectors shown in Table 4 are the ones with the largest number of firms in the sample ${ }^{11}$.

Size is significant and negatively correlated to growth for chemicals, machinery and textiles. The reason is that those industry sectors are characterized by capital intensiveness as opposed to food and garments industries. Therefore, SMEs in these sectors need to achieve economies of scale through fast growth. Exports are also positive and significant for the chemicals and garments industries and negative for the food industry. This can be explained by the fact that chemicals and garments are the sectors with the highest exports in the Greek industry, while the food industry is mainly domestic market oriented.

Size is measured as total assets over the number of employees.

Age is proxied by a dummy that takes the value of 1 for firms with less than 5 years in operation, 2 for firms with more than five but less than 10 years of operation and 3 for firms with more than 10 years of operation (measured by the

\footnotetext{
${ }^{11}$ Results for other industry sub-samples are not presented here for economy of space. Tables and results are available from the authors upon request
} 
Table 4. Panel data analysis - Summary Results for different sub-groups and sectors Dependent Variable: Growth of sales; Method: Pooled Least Squares; Sample: 19881996

\begin{tabular}{|c|c|c|c|c|c|c|c|c|}
\hline \multirow{2}{*}{$\frac{\text { Variable }}{\text { Constant }}$} & \multicolumn{2}{|c|}{ All firms Big cities } & \multicolumn{2}{|c|}{ Periphery Chemical } & \multirow{3}{*}{$\begin{array}{c}\text { Food } \\
0.38 \\
(0.75)\end{array}$} & \multicolumn{3}{|c|}{ Garments Machinery Textiles } \\
\hline & 0.34 & -0.08 & 0.03 & 0.54 & & 0.07 & 1.00 & 0.01 \\
\hline & $(2.40)^{*}$ & $(-0.58)$ & $(0.10)$ & $(1.20)$ & & $(0.20)$ & $(2.04)^{*}$ & $(0.02)$ \\
\hline \multirow[t]{2}{*}{ Size } & -0.03 & -0.04 & -0.04 & -0.28 & -0.08 & -0.11 & -0.08 & -0.20 \\
\hline & $(-1.68)$ & $(-1.59)$ & $(-1.34)$ & $(-4.20)^{*}$ & $(-0.83)$ & $(-1.37)$ & $(-1.95)^{* *}$ & $(-2.92)^{*}$ \\
\hline \multirow[t]{2}{*}{ Age } & 0.01 & 0.02 & 0.00 & -0.03 & 0.04 & 0.02 & 0.01 & -0.06 \\
\hline & $(0.87)$ & $(1.44)$ & $(-0.03)$ & $(-0.77)$ & $(0.90)$ & $(0.67)$ & $(0.31)$ & $(-1.68)$ \\
\hline \multirow[t]{2}{*}{ Exports } & 0.0002 & 0.0003 & -0.0003 & 0.01 & -0.004 & 0.005 & -0.004 & -0.006 \\
\hline & $(1.39)$ & $(2.18)^{*}$ & $(-0.47)$ & $(4.34)^{*}$ & $(-2.31)^{*}$ & $(2.17)^{*}$ & $(-1.44)$ & $(-0.31)$ \\
\hline \multirow[t]{2}{*}{ Profitability } & 0.47 & 0.57 & 0.26 & 0.35 & 0.71 & 0.42 & 0.24 & 0.87 \\
\hline & $(4.72)^{*}$ & $(4.80)^{*}$ & (1.46) & (1.02) & $(1.98)^{* *}$ & (1.33) & $(0.81)$ & $(3.48)^{*}$ \\
\hline \multirow[t]{2}{*}{ Liquidity } & -0.02 & -0.01 & -0.04 & -0.05 & -0.03 & -0.04 & -0.03 & -0.03 \\
\hline & $(-2.79)^{*}$ & $(-1.15)$ & $(-2.74)^{*}$ & $(-1.76)$ & $(-0.98)$ & $(-1.07)$ & $(-1.16)$ & $(-1.41)$ \\
\hline Managerial & 0.21 & 0.26 & 0.10 & -0.25 & 0.44 & -0.02 & 0.26 & -0.12 \\
\hline Performance & $(3.98)^{*}$ & $(3.99)^{*}$ & $(1.10)$ & $(-1.25)$ & $(2.65)^{*}$ & $(-0.12)$ & (1.66) & $(-0.66)$ \\
\hline Admini- & 0.003 & 0.05 & 0.07 & 0.25 & 0.03 & 0.11 & 0.002 & 0.24 \\
\hline Stration & $(2.43)^{*}$ & $(2.02)^{*}$ & $(2.11)^{*}$ & $(3.76)^{*}$ & $(0.34)$ & $(1.30)$ & $(0.06)$ & $(3.08)^{*}$ \\
\hline \multirow[t]{2}{*}{ Credit policy } & -0.05 & -0.04 & -0.07 & 0.07 & -0.04 & 0.04 & -0.06 & -0.06 \\
\hline & $(-6.17)^{*}$ & $(-3.47)^{*}$ & $(-3.64)^{*}$ & $(1.55)$ & $(-1.02)$ & $(0.85)$ & $(-2.63)^{*}$ & $(-0.17)$ \\
\hline Capital & -0.009 & -0.008 & -0.01 & 0.001 & 0.007 & -0.007 & -0.01 & -0.009 \\
\hline Turnover & $(-2.73)^{*}$ & $(-2.56)^{*}$ & $(-1.89)^{*}$ & $(0.40)$ & $(0.03)$ & $(-1.31)$ & $(-1.54)$ & $(-2.41)^{*}$ \\
\hline $\mathrm{T}$ & 9 & 9 & 9 & 9 & 9 & 9 & 9 & 9 \\
\hline $\mathrm{N}$ & 143 & 104 & 39 & 13 & 10 & 16 & 19 & 13 \\
\hline Obs & 1287 & 936 & 351 & 117 & 90 & 144 & 171 & 117 \\
\hline $\mathrm{R}^{2}$ & 0.293 & 0.300 & 0.314 & 0.462 & 0.385 & 0.304 & 0.363 & 0.486 \\
\hline Adjusted $\mathrm{R}^{2}$ & 0.287 & 0.291 & 0.291 & 0.399 & 0.294 & 0.244 & 0.315 & 0.425 \\
\hline F-statistics & $14.55^{*}$ & $11.33^{*}$ & $4.85^{*}$ & $4.22 *$ & $2.02 *$ & $1.72 * *$ & $3.39 *$ & $4.72 *$ \\
\hline
\end{tabular}

**** indicate statistical significance at the $95 \%$ and $90 \%$ level of confidence, one-tailed test.

age of firm in 1988).

Exports is proxied by percentage of exports over sales.

Profitability is net profit over total assets (X13).

Liquidity is measured as current assets to current liabilities (X1).

Managerial Performance is proxied by long-term debt over total debt (X3).

Administration is proxied by sales over number of employees (X8).

Credit Policy is measured by creditors over sales (X6).

Capital Turnover is measured by sales to net fixed assets (X9).

Concerning the other independent variables found to be significant 
determinants of SMEs growth in the all firms model, a great variation is exhibited. In all cases, 2-3 variables were found significant as opposed to 6 variables in the all firms model (column 2 in Table 4).

\section{Conclusions and Policy Implications}

The aim of this paper was to identify what factors contribute to manufacturing SMEs growth in Greece. Based on the reviewed literature and along with the availability of financial and other data offered by ICAP, a private Greek database company, we have identified several variables, mainly financial management and firm productivity indices. We use a stepwise regression analysis on a sample of 143 firms, adding one more explanatory variable to the equation that tries to identify the primary determinants of small firms fast growth. We confirm some prior findings in EU, using additional financial management indexes, such as employee productivity, inventory management, supplier's credit and a decomposition analysis of firm leverage. Additionally, parsimonious models of sub-samples for big cities and peripheral firms, as well as, different industry sectors were developed for a comparative analysis.

Factors found to influence significantly manufacturing small firm growth in Greece are:

- profitability of total assets (positively)

- liquidity (negatively)

- long-term debt reliance (positively)

- employee productivity (positively)

- credit policy (negatively) and

- fixed assets turnover (negatively)

Business size (smaller is better) was shown significant when entered by itself, but its significance decreased when other explanatory variables were added. Also, in the case where Total assets were used as size variable, it did not show any significance at all. Since in most firms the number of employees does not change significantly throughout all years, we just have the same vector in both regressions and the only effect goes to the constant.

Exports and age were not found to be significant in this study as opposed to findings of other studies abroad. However, from the parsimonious models, exports came out as important factor for growth for big-cities-SMEs (Athens $\tilde{n}$ 
Thessalonica) and for specific industry sectors (chemicals and garments). The negative sign of exports in the case of periphery firms and certain industry sectors could be explained by the fact that those firms are oriented towards the domestic market.

We demonstrated that as far as reliance on Debt (high), liquidity (low), credit policy (restricted), capital intensity (i.e. low Fixed Assets turnover) and size (small) significantly related to fast growth, are confirmations of previous research. Greek manufacturing SMEs are largely influenced by the same factors as reported for other EU countries, such as, U.K., (liquidity, debt leverage, fixed asset turnover, size), Sweden, Germany (size), Spain (debt leverage), as well as, U.S. (fixed assets turnover) and Australia. Moreover, this paper identifies two other factors of SMEs growth in Greece, namely (a) the employee productivity measured as sales per employee and (b) the profitability of total assets. The latter constituted a point of doubt up to the present time.

Our findings also suggest that SMEs located in big cities behave differently from firms located in the periphery with regards to factors related to growth. We found that exports, asset profitability and long term leverage are related to fast growth for big city firms as opposed to periphery. This probably means that export activity supported by efficient use of long-term debt characterizes big-city-SMEs. The same holds also for SMEs in different industry sectors.

With the accession of Greece into the European Union, the manufacturing sector passed from an overprotective economy into a competitive environment. European Unification has showed that many Greek manufacturing firms considered being as competitive, in reality they were not. Indeed, European Unification brought on the surface the duality of the Greek industry. A few large enterprises connected with global cheap sources of capital had been developed over time into aggressive cooperation extending and diversifying their production and sales. The majority though of Greek firms, especially the small and medium sized ones, focused into decreasing their labour costs. Clearly, in an internationally competitive environment this is not enough. Indeed, in order to take advantage of the benefits of the enlarged European Integrated market, SMEs should find ways to improve their competitiveness by lowering production costs and adding new technology and innovation into their production process and products. Greek manufacture cannot base anymore its competitiveness on lower labor cost.

Our findings imply that Greek SMEs are in a critical need for:

- improved financial management

- organization structure and administrative procedures to increase employee pro- 
ductivity

- adoption of advanced financial management practices in investment evaluation and

- undertaking of new technology investments.

The direction of the Greek manufacture towards the export market is crucial for the Greek economy, given that the other exporting industry of Greece, namely Tourism is characterized by instability due to the international economic slowdown followed the September $11^{\text {th }}$ of 2001. Economic development depends substantially on the industrial sector and especially on SMEs. European Integration offers now to the Greek industry the possibility to reorganize itself through the entrance of Euro, the flow of funds from the European programs, the Olympic Games of 2004 and the current low interest rates set by the European Central Bank.

Government policy measures that could help Greek manufacturing SMEs to achieve fast growth could consist of provision of:

- easy access to financing at low cost

- lower tax burdens for manufacturing SMEs

- incentives for new investments, especially in the application of new technology,

- facilitating of exports by promoting e-commerce and providing the necessary information and help to establish partnerships of Greek manufacturing SMEs with foreign firms, especially in the form of supplier of goods or semi-finished products,

- incentives for continuous training of management and employees on new technologies and contemporary methods of financial management and strategic planning,

- incentives for cooperation with higher education institutes on R\&D and application of new technology,

- necessary infrastructure for the use of external information and advice services.

Received 18 May 2002, Accepted 25 March 2003

\section{References}

Acs, Z. and D. Audretsch (1990), "The Determinants of Small-Firm Growth in U.S. 
Manufacturing”, Applied Economics, 22, 143-153.

Almus, M. and E.A. Nerlinger (1999), "Growth of New Technology Based Firms:

Which Factors Matter?", Small Business Economics, 13, 141-154.

Anagnostaki, V. and H. Louri (1995), "Manufacturing Entry in Greece 1982-99: Did sectoral policy work?", Journal of Economic Studies, 22:6, 60-68.

(1994), "Determinants of Entry in Greek Manufacturing Industry 1982-88”, Greek Economic Review, 16:1.

Arellano, Manuel y Bover, Olympia (1990). "La econometría de datos de panel", Investigaciones Económicas, vol. XIV, nº 1, pp. 3-45.

Baltagi, Badi H. (1995), Econometric Analysis of Panel Data. John Wiley \& Sons.

Berkham, R., G. Gudgin, M. Hart and E. Hanvey (1996), "The Determinants of Small Firm Growth - An Inter-Regional Study in the U.K.: 1986-90", London: Jessica Kingsley.

Brockhaus, R. and P. Horwitz (1985), "The Psychology of the Entrepreneur", in The Art and Science of Entrepreneurship (Eds.) Sexton D. and R. Smilor Ballinger, Cambridge, MA, pp. 25-48.

Chassid, I. and G. Katsos (1992), European Integration and Greek Industry, IOBE, Athens (in Greek), 167-180.

Davidsson, P., B. Kirchhoff, A. Hatemi-J and H. Gustavsson (2000), Factors Underlying Business Growth In Sweden, ICSB World Conference, June 7-10, Bisbane, Australia.

Derksen, S. and H. J. Keselman (1992), "Backward, forward and stepwise automated subset selection algorithms: Frequency of obtaining authentic and noise variables" British Journal of Mathematical and Statistical Psychology 45: 265-282.

Droukopoulos V. and S. Thomadakis (1993), "The Share of Small and Medium-sized Enterprises in Greek Manufacturing", Small Business Economics, 187-196.

Evans, D.S. (1987), “Tests of Alternative Theories of Firm Growth”, Journal of Political Economy, 95, 657-674.

EOMMEX, (2000), National Policies for Greek SMEs, EOMMEX studies, Greece.

European Observatory for SMEs, 1996, 1997.

Gibb, A. and G. Davies (1990), "In Pursuit Of Frameworks For The Development Of Growth Models Of Small Business", International Small Business Journal, 9(1), 1531.

Gupta, M.C. (1969), "The Effects Of Size, Growth And Industry On The Financial Structure Of Manufacturing Companies", Journal of Finance, 24, 517-529.

Haati, A., G. Hall and R. Donkels (1998), The Internationalization of SMEs, Routledge. Hall, B.H. (1987), "The Relationship Between Firm Size and Firm Growth in the U.S. Manufacturing Sector", Journal of Industrial Economics, 35, 583-606.

Hall, G. (1994), "Factors Distinguishing Survivors from Failures Amongst Small Firms in the U.K. Construction Sector", Journal of Management Studies, 31(5), 737-760.

Hausman, J.A. (1978), "Specification tests in econometrics", Econometrica, 46, pp. 12511271.

Holmes, S. and I. Zimmer (1994), "The Nature of Small Firm: Understanding the 
Motivations of Growth and Non-growth Oriented Owners", Australian Journal of Management, 19(1), 97-120.

Hutchinson, P. and G. Ray (1986), "Surviving the Financial Stress of Small Enterprise Growth", in The Survival of the Small Firm Volume 1: The Economics of Survival and Entrepreneurship, (Eds.) J. Curran, J. Stanworth and D. Watkins, Gower Publishing, Aldershot, England, 53-71.

Jones, L. (1992), "How to Obtain a Small Business Loan”, Economic Development Review, 10, (2), 74-77.

KEPE (Center of Economic Planning and Research), (1989), Small and Medium sized Enterprises (SMEs). Reports for the Program 1988-1992, (in Greek).

Malecki, E. and D. Tootle (1996), "The Role of Networks in Small Firm Competitiveness", International Journal of Technology Management, 11(3), 43-57.

McMahon R.G.P. (2000), "Growth and Performance of Manufacturing SMEs: The Influence of Financial Management Characteristics", Flinders University of South Australia, Scholl of Commerce, Research paper series 99-1, ISSN: 1441-3906.

Mira S. F. (2002), "On capital structure in the small and medium enterprises: the Spanish case". No 2, 2002, El Instituto de Estudios Europeos de la Universidad San Pablo CEU, Polo Europeo Jean Monet.

National Statistical Service of Greece (1997), Positive and Negative Impacts of SMP on Greek Enterprises, Athens.

OECD (2000), The OECD Small and Medium Enterprise Outlook, 2000 Edition.

O'Farrell, P.N. and D.M.W.N. Hitchens (1988), “Alternative Theories of Small-firm Growth: a Critical Review", Environment and Planning A, 20(2), 1365-1383.

Ray, G. and P.J. Hutchinson (1983), "The Financing and Financial Control of Small Enterprise Development", Gower Publishing, Aldershot, England.

Roper, S. (1999), "Modelling Small Business Growth and Profitability", Small Business Economics, 13, 235-252.

Storey, D. (1994), Understanding the Small Business Sector, Rutledge, London.

Wagner, J. (1995), "Exports, Firm Size, Firm Growth and Firm Dynamics", Small Business Economics, 4, 29-39.

Wijewardena, H. and G.E. Tibbits (1999), "Factors Contributing to the Growth of Small Manufacturing Firms: Data from Australia”, Journal of Small Business Management, 37(2), 88-96.

Voulgaris, F., D. Asteriou and G. Agiomirgianakis (2000), "Financial Development and Financial Structure of Industrial SMEs: The Case of Greece", European Research Studies, vol. III, Issue (3-4), 95-109. 